\title{
Photocatalytic Removal of Dye and Reaction Mechanism Analysis over $\mathrm{Y}_{2} \mathrm{O}_{3}$ Composite Nanomaterials
}

\author{
Xiaohui Guo ${ }^{1, a}$, Jinyan Liu ${ }^{1}$ and Guibao Guo ${ }^{1}$ \\ ${ }^{1}$ School of Chemistry and Chemical Engineering, Inner Mongolia University of Science \& Technology, Baotou \\ 014010, Inner Mongolia, China
}

\begin{abstract}
Y}_{2} \mathrm{O}_{3}$ supported photocatalysts $\mathrm{MOx}(\mathrm{M}=\mathrm{Fe}$, Ti and $\mathrm{Bi}) / \mathrm{Y}_{2} \mathrm{O}_{3}$ were synthesized by hydrothermal and deposition-precipitation method and used in photocatalytic degradation of xylenol orange and rhodamine B under UV light irradiation. The crystalline structure and optical properties were well characterized by XRD and UV-vis DRS. The results of XRD revealed that the $\mathrm{MOx} / \mathrm{Y}_{2} \mathrm{O}_{3}$ were composed of $\mathrm{Fe}_{2} \mathrm{O}_{3}, \mathrm{TiO}_{2}, \mathrm{Bi}_{0.8} \mathrm{Y}_{1.2} \mathrm{O}_{3}$ and $\mathrm{Y}_{2} \mathrm{O}_{3}$. The UV-vis DRS showed that $\mathrm{MOx} / \mathrm{Y}_{2} \mathrm{O}_{3}$ photocatalysts exhibited stronger absorption in ultraviolet, and the absorption edge shifted to visible light region significantly. The photocatalytic experiments indicated that $\mathrm{MOx} / \mathrm{Y}_{2} \mathrm{O}_{3}$ photocatalysts showed better activity for photodegradation of xylenol orange than rhodamine $\mathrm{B}$. Moreover, the role of $\mathrm{Y}_{2} \mathrm{O}_{3}$ and the mechanism of photocatalysis is proposed.
\end{abstract}

\section{Introduction}

Rare earth (RE) elements are extensively exploited in metallurgical machinery, petroleum chemical industry, glass-ceramics, agriculture and functional materials due to their unique optical, electrical, magnetic and catalytic properties. However, the imbalance exploitation of RE elements severely restricted the development of RE industry, especially the overcapacity of light RE elements Ce, La and $\mathrm{Y}$, so it is very important to tackle the application of light RE elements. Light RE elements as catalysts or catalytic components has been widely applied in petroleum chemical industry, catalytic combustion of fossil fuels, automotive emissions control, the purification of industrial waste air, and solid solution fuel cells [1] and showed excellent performance, that was ascribed to be one of the most effective way of application and foreground.

Photocatalysis is a promising technology for solving energy and environmental issues. In most of rare earth oxides, $\mathrm{CeO}_{2}$ has been successfully used as photocatalysts to degrade sewage and pollutants because of its strong redox properties of $\mathrm{Ce}^{3+} / \mathrm{Ce}^{4+}$ and the formation of oxygen vacancies [2, 3]. While La and $\mathrm{Y}$ only acted as dopant in photocatalysts, such as $\mathrm{La} / \mathrm{Y}$ doped $\mathrm{TiO}_{2}$ [4-6], $\mathrm{Y}_{2} \mathrm{O}_{3}-\mathrm{ZnO}$ [7], $\mathrm{Y}$ doped graphene oxide [8] and $\mathrm{La}_{2} \mathrm{O}_{3}-\mathrm{Bi}_{2} \mathrm{O}_{3}$ [9], had been synthesized to photocatalytic degradation of dye wastewater. The major role of RE ions in doped photocatalysts is supposed to enhance electron-hole pairs separation, improve optical absorption properties, modify adsorption capacity of dye and increase surface concentration of adsorbed OH group [10-13]. Nonetheless, the mechanism and active species of $\mathrm{Y}$ doped photocatalysts has not been thoroughly studied.

\footnotetext{
${ }^{\mathrm{a}}$ Corresponding author : gxhsxicc@163.com
} 
In this work, $\mathrm{Y}_{2} \mathrm{O}_{3}$ supported photocatalysts were synthesized via hydrothermal and depositionprecipitation method. XRD and UV-vis diffuse reflectance spectra were carried out to characterize the crystalline structure and optical property. The photocatalytic activity was tested by degradation of xylenol orange $(\mathrm{XO})$ and rhodamine $\mathrm{B}(\mathrm{RhB})$ aqueous solutions under UV light irradiation. The photocatalytic mechanism is proposed based on the band potential analysis and active species trapping experiment.

\section{Experimental}

\subsection{Catalyst preparation}

All chemical reagents were of analytical grade and used without further purification. $\mathrm{MO}_{\mathrm{x}} / \mathrm{Y}_{2} \mathrm{O}_{3}$ supported photocatalysts were synthesized by two-step (hydrothermal and deposition-precipitation) process. Firstly, $\mathrm{Y}_{2} \mathrm{O}_{3}$ support was prepared as follows: $2 \mathrm{mmol} \mathrm{Y}\left(\mathrm{NO}_{3}\right)_{3} \cdot 6 \mathrm{H}_{2} \mathrm{O}$ was dissolved in 20 $\mathrm{mL}$ of deionized water, and then $60 \mathrm{~mL} \mathrm{KOH}$ aqueous solution $(5 \mathrm{~mol} / \mathrm{L})$ was added into the solution to form white precipitation. After being magnetically stirred for $1 \mathrm{~h}$, the mixture was transferred into a $100 \mathrm{~mL}$ Teflon-lined autoclave which was subsequently heated at $180{ }^{\circ} \mathrm{C}$ for $12 \mathrm{~h}$. After cooling down to room temperature, the solid products were filtered, washed with deionized water, dried at $60{ }^{\circ} \mathrm{C}$ overnight, calcined at $500{ }^{\circ} \mathrm{C}$ for $5 \mathrm{~h}$, and finally $\mathrm{Y}_{2} \mathrm{O}_{3}$ powder was obtained.

Secondly, $\mathrm{MO}_{\mathrm{x}} / \mathrm{Y}_{2} \mathrm{O}_{3}$ photocatalysts were prepared by deposition-precipitation methods. Typically, $0.2 \mathrm{~g}$ of the as-prepared $\mathrm{Y}_{2} \mathrm{O}_{3}$ powder was dispersed in $20 \mathrm{~mL}$ of deionized water and sonicated for 30 min, and then desired amount of $20 \mathrm{~mL}$ of $\mathrm{Fe}\left(\mathrm{NO}_{3}\right)_{3} \cdot 9 \mathrm{H}_{2} \mathrm{O}$ aqueous solution was added. The suspension was magnetically stirred for $30 \mathrm{~min}$ and $40 \mathrm{~mL}$ of $\mathrm{K}_{2} \mathrm{CO}_{3}$ solution $(0.5 \mathrm{~mol} / \mathrm{L})$ was added under vigorous stirring for $3 \mathrm{~h}$. Subsequently, the mixtures were filtered, washed with deionized water, dried at $60{ }^{\circ} \mathrm{C}$ overnight, calcined at $500{ }^{\circ} \mathrm{C}$ for $2 \mathrm{~h}$, and finally $\mathrm{FeO}_{\mathrm{x}} / \mathrm{Y}_{2} \mathrm{O}_{3}$ samples were obtained. $\mathrm{Bi}_{2} \mathrm{O}_{3} / \mathrm{Y}_{2} \mathrm{O}_{3}$ sample was synthesized by analogous procedure, except that $\mathrm{Bi}\left(\mathrm{NO}_{3}\right)_{3} \cdot 5 \mathrm{H}_{2} \mathrm{O}$ was dissolved in $5 \mathrm{~mL}$ of $1 \mathrm{~mol} / \mathrm{L} \mathrm{HNO}_{3}$ solution. While $\mathrm{TiO}_{2} / \mathrm{Y}_{2} \mathrm{O}_{3}$ sample was prepared as follow: $0.3 \mathrm{ml}$ of tetrabutyl titanate was added into $80 \mathrm{ml}$ of ethanol solution containing $0.2 \mathrm{~g}$ of $\mathrm{Y}_{2} \mathrm{O}_{3}$ powder and sonicated for $30 \mathrm{~min}$ to form mixture A, and then $1 \mathrm{ml} \mathrm{NH} \cdot \mathrm{H}_{2} \mathrm{O}(25 \%-28 \%)$ was added dropwise into A to make titanium source hydrolyze accompanying with continuously stirring at room temperature for $3 \mathrm{~h}$. The resulting mixture dried by rotary evaporation at $80{ }^{\circ} \mathrm{C}$, calcined at $500{ }^{\circ} \mathrm{C}$ for $2 \mathrm{~h}$, and finally the product was denoted as $\mathrm{TiO}_{2} / \mathrm{Y}_{2} \mathrm{O}_{3}$. The weight contents of $\mathrm{MO}_{\mathrm{x}}$ in all of $\mathrm{MO}_{\mathrm{x}} / \mathrm{Y}_{2} \mathrm{O}_{3}$ photocatalysts were $25 \%$.

\subsection{Characterization}

Powder X-ray diffraction profiles were performed on Bruker D8 ADVANCE diffractometer at a scanning rate of $5^{\circ} / \mathrm{min}$ in the $2 \theta$ range from $20^{\circ}$ to $80^{\circ}$, with $\mathrm{Cu} \mathrm{K \alpha}$ radiation $(\lambda=1.5406 \AA)$ at $40 \mathrm{kV}$ and $40 \mathrm{~mA}$. Diffuse reflectance spectra (DRS) were carried out on Agilent Cary $100 \mathrm{UV}$-vis spectrophotometer in the range of $200-800 \mathrm{~nm}$ using $\mathrm{BaSO}_{4}$ as reference.

\subsection{Photocatalytic activity}

The photocatalytic activity of all samples was evaluated toward photodegradation of xylenol orange (XO) and rhodamine $\mathrm{B}(\mathrm{RhB})$ aqueous solutions under UV light irradiation $(8 \mathrm{~W}, \lambda=365 \mathrm{~nm})$. In details, $100 \mathrm{~mL}$ suspension containing $0.2 \mathrm{~g} / \mathrm{L}$ of catalyst and $20 \mathrm{mg} / \mathrm{L}$ of $\mathrm{XO}$ or $\mathrm{RhB}$ was sonicated for $5 \mathrm{~min}$, magnetically stirred in dark for $1 \mathrm{~h}$ to ensure an adsorption-desorption equilibrium, and then irradiated under UV light. Simultaneously, at given intervals, small aliquots of suspension were sampled and centrifuged to remove catalysts. The $\mathrm{XO}$ or $\mathrm{RhB}$ concentrations in filtrates were analyzed on UV-vis spectrophotometer (Analytik Jena, SPECORD 50) in the range of 200-700 nm using $\mathrm{H}_{2} \mathrm{O}$ as reference. 
The process of active species trapping experiments is the same as photocatalytic tests; besides, ascorbic acid (AA, $0.1 \mathrm{mmol} / \mathrm{L})$, triethanolamine (TEOA, $0.01 \mathrm{~mol} / \mathrm{L}$ ) and t-butanol $(\mathrm{TBA}, 0.01$ $\mathrm{mol} / \mathrm{L})$ were added to dye solution to trap the superoxide radicals $\left(\cdot \mathrm{O}_{2}^{-}\right)$, holes $\left(h^{+}\right)$and hydroxyl radicals $(\cdot \mathrm{OH})$, respectively.

\section{Results and discussion}

\subsection{Characterization of catalysts}

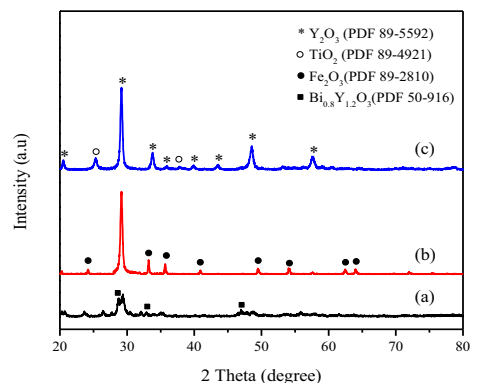

Figure 1. $\mathrm{XRD}$ patterns of $\mathrm{MO}_{\mathrm{x}} / \mathrm{Y}_{2} \mathrm{O}_{3}$ samples (a) $\mathrm{Bi}_{2} \mathrm{O}_{3} / \mathrm{Y}_{2} \mathrm{O}_{3}$, (b) $\mathrm{Fe}_{2} \mathrm{O}_{3} / \mathrm{Y}_{2} \mathrm{O}_{3}$, (c) $\mathrm{TiO}_{2} / \mathrm{Y}_{2} \mathrm{O}_{3}$

Fig. 1 shows the XRD patterns of $\mathrm{MO}_{\mathrm{x}} / \mathrm{Y}_{2} \mathrm{O}_{3}$ photocatalysts. For $\mathrm{Bi}_{2} \mathrm{O}_{3} / \mathrm{Y}_{2} \mathrm{O}_{3}$ (Fig.1a), two sets of XRD peaks of cubic $\mathrm{Y}_{2} \mathrm{O}_{3}$ (PDF 89-5592) and cubic $\mathrm{Bi}_{0.8} \mathrm{Y}_{1.2} \mathrm{O}_{3}$ (PDF 50-916) were observed. Compared with $\mathrm{Fe}_{2} \mathrm{O}_{3} / \mathrm{Y}_{2} \mathrm{O}_{3}$ and $\mathrm{TiO}_{2} / \mathrm{Y}_{2} \mathrm{O}_{3}$ samples, the intensity of diffraction peaks ascribed to $\mathrm{Y}_{2} \mathrm{O}_{3}$ dramatically decreased indicating the low degree of crystallinity, this is because $\mathrm{Y}_{2} \mathrm{O}_{3}$ can partly dissolve in $\mathrm{HNO}_{3}$ and precipitate with $\mathrm{Bi}^{3+}$ together in the process of preparation. $\mathrm{For} \mathrm{Fe}_{2} \mathrm{O}_{3} / \mathrm{Y}_{2} \mathrm{O}_{3}$ and $\mathrm{TiO}_{2} / \mathrm{Y}_{2} \mathrm{O}_{3}$ samples (Fig. $1 \mathrm{~b}$ and c), the support $\mathrm{YO}_{3}$ is indexed to cubic structure of $\mathrm{Y}_{2} \mathrm{O}_{3}(\mathrm{PDF}$ 895592), its diffraction peak shape is irrelevant to loaded metals (Fe or Ti), and the second components can be indexed to hematite $\alpha-\mathrm{Fe}_{2} \mathrm{O}_{3}$ (PDF 89-2810) and anatase $\mathrm{TiO}_{2}$ (PDF 89-4921), respectively.
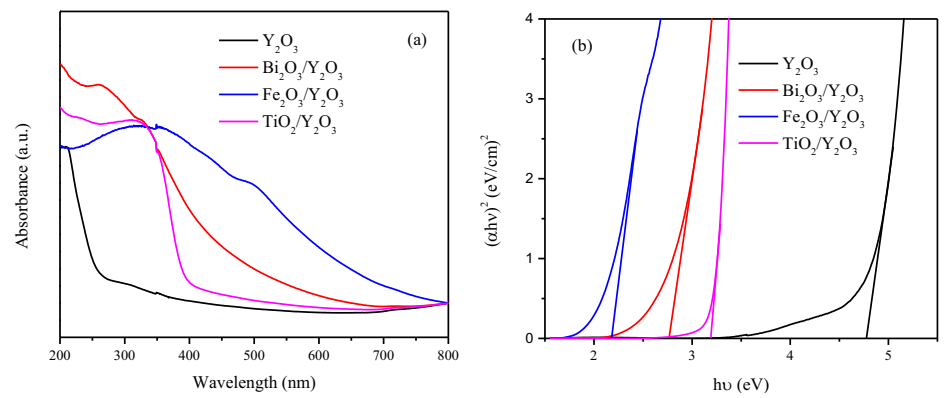

Figure 2. UV-vis absorbance spectra (a) and plot of $(\alpha h v)^{2}$ versus $h v(b)$ of $\mathrm{MO}_{\mathrm{x}} / \mathrm{Y}_{2} \mathrm{O}_{3}$ samples

The UV-vis diffuse reflectance spectra (DRS) of $\mathrm{Y}_{2} \mathrm{O}_{3}$ and $\mathrm{MO}_{\mathrm{x}} / \mathrm{Y}_{2} \mathrm{O}_{3}$ photocatalysts were displayed in Fig.2. Taking pure $\mathrm{Y}_{2} \mathrm{O}_{3}$ support for comparison, supported $\mathrm{MO}_{\mathrm{x}} / \mathrm{Y}_{2} \mathrm{O}_{3}$ photocatalysts exhibited stronger absorption in ultraviolet, and the absorption edge shifted to visible light region significantly, especially for $\mathrm{Fe}_{2} \mathrm{O}_{3} / \mathrm{Y}_{2} \mathrm{O}_{3}$, which is responsive to visible light nearly to $800 \mathrm{~nm}$. Moreover, $\mathrm{Bi}_{2} \mathrm{O}_{3} / \mathrm{Y}_{2} \mathrm{O}_{3}$ possessed strongest absorption in UV range indicating more active species $(\cdot \mathrm{OH})$ produced on the surface of sample [7].

The band gaps $\left(E_{g}\right)$ of $\mathrm{MO}_{\mathrm{x}} / \mathrm{Y}_{2} \mathrm{O}_{3}$ composites were calculated from following equation [14]: $\alpha h v=A\left(h v-E_{g}\right)^{n / 2}$, where $\alpha, v, E_{g}$ and $\mathrm{A}$ are the absorption coefficient, light frequency, band gap, and a constant, respectively; $n$ depends on the characteristics of transition in a semiconductor, $n$ is 4 for direct band gap and 1 for indirect band gap. $\mathrm{Y}_{2} \mathrm{O}_{3}$ is indirect band gap, so $n$ is equal to 1 [15]. Fig.2b shows the plot of $(\alpha h v)^{2}$ vs energy $(h v)$ for $\mathrm{MO}_{\mathrm{x}} / \mathrm{Y}_{2} \mathrm{O}_{3}$ composites, the $E_{g}$ can be obtained by 
extrapolating the linear portion of the curve or tail. Compared to pure $\mathrm{Y}_{2} \mathrm{O}_{3}\left(4.76 \mathrm{eV}\right.$ ), $\mathrm{TiO}_{2} / \mathrm{Y}_{2} \mathrm{O}_{3}$, $\mathrm{Bi}_{2} \mathrm{O}_{3} / \mathrm{Y}_{2} \mathrm{O}_{3}$ and $\mathrm{Fe}_{2} \mathrm{O}_{3} / \mathrm{Y}_{2} \mathrm{O}_{3}$ samples possess $E_{g}$ of 3.2, 2.8 and $2.2 \mathrm{eV}$, respectively, representing potential photocatalytic applications under visible light irradiation. The remarkable red shift of UV-vis DRS and reduction in $E_{g}$ of those three supported samples were due to the fact that absorption spectral lines in Fig.2a are the superposition of each individual component. Coupling effectively promote the separation of photogenerated electrons and holes between two composite materials, but don't change their own band gaps. Consequently, the calculated band gap in this work should be attributed to $\mathrm{TiO}_{2}$, $\mathrm{Bi}_{2} \mathrm{O}_{3}$ and $\mathrm{Fe}_{2} \mathrm{O}_{3}$, respectively, and well coincide with the values in Ref. [16].

\subsection{Photocatalytic activity}

Fig.3 reveals the photodegradation activity of $\mathrm{XO}$ and $\mathrm{RhB}$ in the presence of $\mathrm{MO}_{\mathrm{x}} / \mathrm{Y}_{2} \mathrm{O}_{3}$ photocatalysts, and the inset of figure is the structure of $\mathrm{XO}$ and $\mathrm{RhB}$. For photodegradation of $\mathrm{XO}$, $\mathrm{TiO}_{2} / \mathrm{Y}_{2} \mathrm{O}_{3}$ and $\mathrm{Fe}_{2} \mathrm{O}_{3} / \mathrm{Y}_{2} \mathrm{O}_{3}$ samples showed faster photocatalytic rate in the early $90 \mathrm{~min}$. As time increased further, the photodegradation rate of $\mathrm{Bi}_{2} \mathrm{O}_{3} / \mathrm{Y}_{2} \mathrm{O}_{3}$ sample increased rapidly and exceeded that of $\mathrm{Fe}_{2} \mathrm{O}_{3} / \mathrm{Y}_{2} \mathrm{O}_{3}$ sample. Fig.3a shows that the photodegradation of $\mathrm{XO}$ obeys the pseudo-first-order decay kinetics, the rate was illustrated as following formula: $\ln \left(C_{0} / C\right)=k_{\text {app }} \cdot t$, where $k_{\text {app }}$ is the apparent rate constants $\left(\mathrm{min}^{-1}\right)$. Plotting $\ln \left(C_{0} / C\right)$ vs. $t$ gives $k_{\text {app }}$ from slope of linear fit, and keeps linear regression values $R^{2}>0.97$. The $k_{\text {app }}$ were found to be $0.0102,0.0105$ and $0.0120 \mathrm{~min}^{-1}$ for $\mathrm{Fe}_{2} \mathrm{O}_{3} / \mathrm{Y}_{2} \mathrm{O}_{3}$, $\mathrm{Bi}_{2} \mathrm{O}_{3} / \mathrm{Y}_{2} \mathrm{O}_{3}$ and $\mathrm{TiO}_{2} / \mathrm{Y}_{2} \mathrm{O}_{3}$, respectively, implying $\mathrm{TiO}_{2} / \mathrm{Y}_{2} \mathrm{O}_{3}$ sample have the best photocatalytic activity.
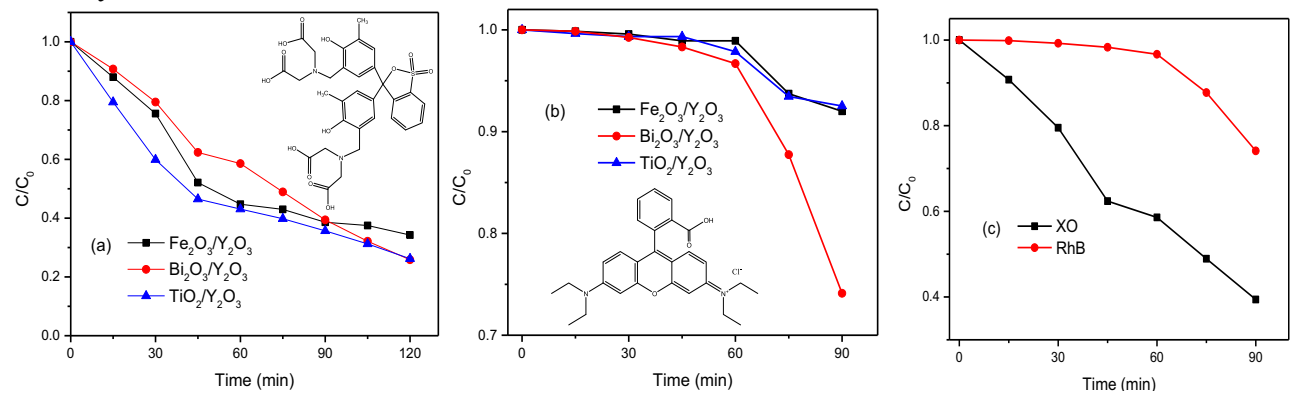

Figure 3. Photodegradation performance of (a) XO, (b) $\mathrm{RhB}$ over $\mathrm{MO}_{\mathrm{x}} / \mathrm{Y}_{2} \mathrm{O}_{3}$, and (c) comparison of photodegradation activity over $\mathrm{Bi}_{2} \mathrm{O}_{3} / \mathrm{Y}_{2} \mathrm{O}_{3}$ catalyst. $(20 \mathrm{mg}$ of catalyst, $100 \mathrm{~mL}$ of XO/RhB aqueous solution 20 $\mathrm{mg} / \mathrm{L})$

Whereas for photodegradation of $\mathrm{RhB}$, the photodegradation rate of three samples increased very slowly in $60 \mathrm{~min}$, then raised approximately linearly in the last $30 \mathrm{~min}$, and $\mathrm{Bi}_{2} \mathrm{O}_{3} / \mathrm{Y}_{2} \mathrm{O}_{3}$ sample performed the highest activity within $90 \mathrm{~min}$. Nevertheless, all of three samples showed very low activity for photodegradation of $\mathrm{RhB}$ compared to photodegradation of $\mathrm{XO}$, this was seen obviously in Fig.3c. The activity difference between $\mathrm{XO}$ and $\mathrm{RhB}$ might be derived from their molecular structure difference. From inset of Fig.3a and b, XO with four carboxylmethyl groups are more apt to be adsorbed on alkaline surface and subsequently photodegraded by photocatalysts than RhB that has only one carboxyl group. Further, the anion $\mathrm{Cl}^{-}$in $\mathrm{RhB}$ is detrimental to photodegradation reaction owing to scavenging of active sites [17].

\subsection{Postulated mechanism}

To illustrate the photocatalytic mechanism of $\mathrm{MO}_{\mathrm{x}} / \mathrm{Y}_{2} \mathrm{O}_{3}$ and explain the origin of active species, the role of $\mathrm{Y}_{2} \mathrm{O}_{3}$ was analyzed. $\mathrm{Y}_{2} \mathrm{O}_{3}$, as a basic oxide, is abundant with surface hydroxyl and adsorbed oxygen [18], and that facilitates the photocatalytic oxidation of dye. On the other hand, coupling of band gaps between $\mathrm{Y}_{2} \mathrm{O}_{3}$ and $\mathrm{MO}_{\mathrm{x}}$ should be taken into account. 
The relative positons of valence band (VB) and conduction band (CB) edges was calculated as following [19, 20]: $E_{C B}=\chi-E_{e}-0.5 \cdot E_{g}$ and $E_{V B}=E_{C B}+E_{g}$, where $E_{C B}$ and $E_{V B}$ are the CB and VB edge potential, $\chi$ is the absolute electronegativity, $E_{e}$ is the energy of free electrons at the hydrogen scale (about $4.5 \mathrm{eV}), E_{g}$ is the band gap. The calculated $E_{V B}$ and $E_{C B}$ were listed in Table 1.

Table 1. Absolute electronegativity $(\chi)$, Band gap $\left(\mathrm{E}_{\mathrm{g}}\right)$, energy levels of calculated conduction band edge $\left(\mathrm{E}_{\mathrm{CB}}\right)$ and valence band edge $\left(\mathrm{E}_{\mathrm{VB}}\right)$ with respect to normal hydrogen electrode (NHE) for metal oxides.

\begin{tabular}{|l|c|c|c|c|}
\hline Metal oxide & $\mathrm{X}(\mathrm{eV})$ & $\mathrm{E}_{\mathrm{g}}(\mathrm{eV})$ & $\mathrm{E}_{\mathrm{CB}}(\mathrm{eV})$ & $\mathrm{E}_{\mathrm{VB}}(\mathrm{eV})$ \\
\hline $\mathrm{Bi}_{2} \mathrm{O}_{3}$ & 6.23 & 2.8 & 0.33 & 3.13 \\
\hline $\mathrm{TiO}_{2}$ & 5.81 & 3.2 & -0.29 & 2.91 \\
\hline $\mathrm{Fe}_{2} \mathrm{O}_{3}$ & 5.88 & 2.2 & 0.28 & 2.48 \\
\hline $\mathrm{Y}_{2} \mathrm{O}_{3}$ & 5.35 & 4.76 & -1.53 & 3.23 \\
\hline
\end{tabular}

The case of $\mathrm{Fe}_{2} \mathrm{O}_{3} / \mathrm{Y}_{2} \mathrm{O}_{3}$ and $\mathrm{TiO}_{2} / \mathrm{Y}_{2} \mathrm{O}_{3}$ were analogous to $\mathrm{Bi}_{2} \mathrm{O}_{3} / \mathrm{Y}_{2} \mathrm{O}_{3}$, so $\mathrm{Bi}_{2} \mathrm{O}_{3} / \mathrm{Y}_{2} \mathrm{O}_{3}$ was analyzed in detail. $\mathrm{Bi}_{2} \mathrm{O}_{3}$ was excited by UV light and generated electrons and holes pairs (Eq.(1)), but they don't transfer to $\mathrm{Y}_{2} \mathrm{O}_{3}$ owing to the mismatch of $\mathrm{CB}$ and $\mathrm{VB}$ edge potential between $\mathrm{Y}_{2} \mathrm{O}_{3}$ and $\mathrm{Bi}_{2} \mathrm{O}_{3}$. On the other side, the CB potential $(0.33 \mathrm{eV})$ [16] of $\mathrm{Bi}_{2} \mathrm{O}_{3}$ is positive than $E\left(\mathrm{O}_{2} / \cdot \mathrm{O}_{2}^{-}\right)(-0.13$ $\mathrm{eV}$ vs. NHE) [8], therefore, the electrons on the $\mathrm{CB}$ of $\mathrm{Bi}_{2} \mathrm{O}_{3}$ don't reduce adsorbed $\mathrm{O}_{2}$ to $\cdot \mathrm{O}_{2}{ }^{-}$. The VB potential $(3.13 \mathrm{eV})[16]$ of $\mathrm{Bi}_{2} \mathrm{O}_{3}$ is positive than $E\left(\mathrm{OH}^{-} / \mathrm{OH}\right)(1.89 \mathrm{eV}$ vs. NHE) [8], and thus the holes on the $\mathrm{VB}$ of $\mathrm{Bi}_{2} \mathrm{O}_{3}$ can oxidized $\mathrm{OH}^{-}$to $\cdot \mathrm{OH}$.

Although the band potential of $\mathrm{Y}_{2} \mathrm{O}_{3}$ don't couple with that of $\mathrm{Bi}_{2} \mathrm{O}_{3}, \mathrm{Y}^{3+}$ was supposed to act intermediate for photogenerated electrons and holes pairs separation, where $\mathrm{Y}^{3+}$ acts as electronacceptor (electron-trap) and electron-donor (hole-trap) to inhibit recombination of charge pairs and is reduced/oxidized to $\mathrm{Y}^{2+} / \mathrm{Y}^{4+}$ individually (Eq. $\left.(2,3)\right)$ [12]. Subsequently, the unstable $\mathrm{Y}^{2+}$ and $\mathrm{Y}^{4+}$ can release trapped $\mathrm{e}^{-} / \mathrm{h}^{+}$pairs through Eq. $(4,5)$ and produce active species $\cdot \mathrm{O}_{2}{ }^{-}$and $\cdot \mathrm{OH}$. The $\cdot \mathrm{O}_{2}{ }^{-}$may further react to from $\cdot \mathrm{OH}$ (Eq.(6)).

$\mathrm{Bi}_{2} \mathrm{O}_{3}+h v \rightarrow \mathrm{e}^{-}+\mathrm{h}^{+}$

$\mathrm{Y}^{3+}+\mathrm{h}^{+} \rightarrow \mathrm{Y}^{4+}$ (hole trap)

$\mathrm{Y}^{3+}+\mathrm{e}^{-} \rightarrow \mathrm{Y}^{2+}$ (electron trap)

$\mathrm{Y}^{2+}+\mathrm{O}_{2}($ ads $) \rightarrow \mathrm{Y}^{3+}+\cdot \mathrm{O}_{2}^{-}$
(1) $\mathrm{Y}^{4+}+\mathrm{OH}^{-}($ads $) \rightarrow \mathrm{Y}^{3+}+\cdot \mathrm{OH}($ ads $)$

(2) $\cdot \mathrm{O}_{2}^{-}+\mathrm{e}^{-}+2 \mathrm{H}^{+} \rightarrow \mathrm{H}_{2} \mathrm{O}_{2} \rightarrow \cdot \mathrm{OH}+\mathrm{OH}^{-}$

(3) $\mathrm{XO}+\left(\cdot \mathrm{O}_{2}^{-}, \cdot \mathrm{OH}\right) \rightarrow$ Degradation products

There are many works explored the photocatalytic active species on various photocatalysts. Chen [21] reported that $\cdot \mathrm{OH}$ was the main active species for $\mathrm{RhB}$ degradation on flower-like $\mathrm{Bi}_{2} \mathrm{O}_{2} \mathrm{CO}_{3}$, while Peng [22] suggested that $h^{+}$and $\cdot \mathrm{O}^{2-}$ are the main active species in $\mathrm{RhB}$ photodecomposition under solar light irradiation on $\mathrm{WO}_{3}-\mathrm{Bi}_{2} \mathrm{WO}_{6}$.

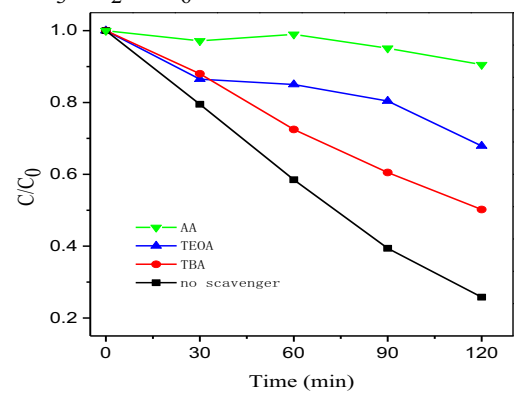

Figure 4. Effect of scavenger on photodegradation performance of $\mathrm{XO}$ aqueous solution over $\mathrm{Bi}_{2} \mathrm{O}_{3} / \mathrm{Y}_{2} \mathrm{O}_{3}$.

(20 mg catalyst, $20 \mathrm{mg} / \mathrm{L}$ of $\mathrm{XO}$ aqueous solution, $100 \mathrm{~mL}, 120 \mathrm{~min}$ )

In order to discriminate the active species in this work, the trapping experiments were carried out as before mentioned. Fig. 4 shows the impact of different scavengers on the photodegradation efficiency over $\mathrm{Bi}_{2} \mathrm{O}_{3} / \mathrm{Y}_{2} \mathrm{O}_{3}$ sample. It is observed that the addition of AA dramatically decreased 
photodegradation activity, the degradation efficiency of XO declined from $74.1 \%$ to $9.5 \%$ (120 min). The addition of TEOA and TBA reduced degradation efficiency of XO to $32.1 \%$ and $49.8 \%$, respectively. These results suggest that $\cdot \mathrm{O}_{2}{ }^{-}$and $\cdot \mathrm{OH}$ are both important for photodegradation of $\mathrm{XO}$ over $\mathrm{Bi}_{2} \mathrm{O}_{3} / \mathrm{Y}_{2} \mathrm{O}_{3}$ sample under UV light irradiation (Eq.(7)).

\section{Conclusions}

In summary, $\mathrm{MO}_{\mathrm{x}}(\mathrm{M}=\mathrm{Fe}, \mathrm{Ti}$ and $\mathrm{Bi}) / \mathrm{Y}_{2} \mathrm{O}_{3}$ supported photocatalysts have been successfully synthesized by hydrothermal and deposition-precipitation method. They exhibited stronger absorption in ultraviolet, the absorption edge shifted to visible light region significantly, and $E_{g}$ was largely reduced with respect to pure $\mathrm{Y}_{2} \mathrm{O}_{3}$. TiO $\mathrm{Ti}_{2} / \mathrm{Y}_{2} \mathrm{O}_{3}$ and $\mathrm{Bi}_{2} \mathrm{O}_{3} / \mathrm{Y}_{2} \mathrm{O}_{3}$ samples showed the highest activity for photodegradation of $\mathrm{XO}$ and $\mathrm{RhB}$, respectively. The major role of $\mathrm{Y}_{2} \mathrm{O}_{3}$ is to enhance the $\mathrm{OH}^{-}$ concentration on the surface of photocatalysts, and $\mathrm{Y}^{3+}$ performed synergistic effects to trap charge pairs and inhibit $\mathrm{e}^{-} / \mathrm{h}^{+}$recombination. The $\cdot \mathrm{O}_{2}{ }^{-}$and $\cdot \mathrm{OH}$ are the main active species for photocatalytic degradation of $\mathrm{XO}$ over $\mathrm{Bi}_{2} \mathrm{O}_{3} / \mathrm{Y}_{2} \mathrm{O}_{3}$ sample.

\section{Acknowledgments}

The authors are grateful for the financial support provided by the Natural Science Foundation of Inner Mongolia of China (Grant No. 2014BS0204), Scientific Research Program in University of Inner Mongolia of China (Grant No. NJZY14163).

\section{References}

1. W. C. Zhan, Y. Guo, X. Q. Gong, Y. C. Guo, Y. Q. Wang, G. Z. Lu, Chin. J. Catal. 35, 1238 (2014)

2. N. S. Arul, D. Mangalaraj, T. W. Kim, P. C. Chen, N. Ponpandian, P. Meena, Y. Masuda, J. Mater Sci: Mater Electron. 24, 1614 (2013)

3. T. Feng, X. D. Wang, G. S. Feng, Mater. Lett. 100, 36 (2013)

4. Y. J. Wang, L. J. Jiang, C. G. Feng, Desalin. Water Treat. 52, 4802 (2014)

5. M. Meksi, G. Berhault, C. Guillard, H. Kochkar, Catal. Comm. 61, 107 (2015)

6. D. M. Tobaldi, R. C. Pullar, A. S. Škapin, M. P. Seabra, J. A. Labrincha, Mater. Res. Bull. 50, 183 (2014)

7. T. M. Su, Z. Z. Qin, H. B. Ji, Y. X. Jiang, Int. J. Photoenergy. doi:10.1155/2014/794057 (2014)

8. Y. Zhang, S. S. Yuan, Y. H. Zhao, H. G. Wang, C. D. He, J. Mater. Chem. A. 2, 7897 (2014)

9. H. Q. Deng, T. Tang, C. H. Fu, Q. Y. Jiang, Y. M. Hu, J. C. Huo, Environ. Sci. Technol. 36, 121 (2013)

10. S. Z. Chen, S. M. Xu, G. Xu, L. Y. Li, Rare Metal Mat. Eng. 35, 505 (2006)

11. L. Y. Lin, M. H. Yeh, C. Y. Chen, R. Vittal, K. C. Ho, J. Mater. Chem. A. 2, 8281 (2014)

12. A. N. Ökte, Ö. Yilmaz, Appl. Catal. B: Environ. 85, 92 (2008)

13. C. J. Hao, J. Li, Z. L. Zhang, Y. J. Ji, H. H. Zhan, F. X. Xiao, D. Wang, B. Liu, F. B. Su, Appl. Surf. Sci. 331, 17 (2015)

14. C. Saranyoo, I. Burapat, W. Khatcharin, Mater. Res. Bull. 54, 28 (2014)

15. P. K. Patel, K. L. Yadav, Physica B. 442, 39 (2014)

16. Y. Xu, M. A. A. Schoonen, Am. Mineral. 85, 543 (2000)

17. D. Kanakaraju, C. A. Motti, B. D. Glass, M. Oelgemöller, Chemosphere. 139, 579 (2015)

18. L. H. Zhao, X. M. Zheng, J. H. Fei, Chin. J. Catal. 17, 227 (1996)

19. M. A. Ahmed, E. E. EI-Katori, Z. H. Gharni, J. Alloys Compd. 553, 19 (2013)

20. H. Tian, F. Teng, J. Xu, S. Q. Lou, N. Li, Y. X. Zhao, M. D. Chen, Sci. Rep. 5, 7770 (2015)

21. L. Chen, R. Huanag, S. F. Yin, S. L. Luo, C. T. Au, Chem. Eng. J. 193-194, 123 (2012)

22. Y. Peng, Q. G. Chen, D. Wang, H. Y. Zhou, A. W. Xu, Cryst. Eng. Comm. 17, 569 (2015) 